Est Ag 52 (2017) 25-52

\title{
Mi amigo Senén Vidal. Una vida fecunda al servicio de la biblia
}

\author{
XABIER PiKAZA
}

RESUMEN: Xabier Pikaza, compañero y amigo de Senén Vidal, recoge los momentos principales de su itinerario vital, docente y teológico, en un trabajo que se divide en dos partes. (a) La primera, de tipo más biográfico, se centra en la tesis doctoral de S. Vidal (1979) y en sus años de docencia en la Universidad Pontificia de Salamanca (1980-1984), exponiendo las razones de su "cese", que ha marcado toda su vida personal e intelectual. (b) La segunda parte de tipo bio-bibliográfico, recoge y analiza los tema y momentos de la investigación de S. Vidal, poniendo de relieve su análisis de "corpus" de Pablo, el despliegue de la historia de Jesús y la traducción y comentario de conjunto del Nuevo Testamento, para terminar evocando el legado de su vida de biblista, que debía terminar con una Historia del Cristianismo Primitivo.

Palabras clave: Análisis histórico-literario. Discípulo "amigo" de Jesús. Estudio Teológico Agustiniano. Jesús. Nuevo Testamento. Pablo. Resurrección. Universidad Pontificia de Salamanca

Summary: Xabier Pikaza, companion and friend of Senén Vidal, collects the main moments of his life, teaching and theological itinerary, in a paper that is divided into two parts. (A) The first, more biographical, focuses on the doctoral thesis of S. Vidal (1979) and the years of his professorship at the Pontifical University of Salamanca (1980-1984), explaining the reasons for his "cessation", which has marked his entire personal and intellectual life. (B) The second part, a bio-bibliographical type, collects and analyzes the themes and moments of S. Vidal's research, highlighting his analysis of Paul's "corpus", the unfolding of Jesus' history and the translation and commentary on the New Testament; it concludes by recalling the legacy of his biblical life, which was to end with a History of Primitive Christianity. 
KEYwORds: Historical-literary analysis. Disciple "friend" of Jesus. Augustinian Theological Study. Jesus. New Testament. Paul. Resurrection. Pontifical University of Salamanca

No tengo distancia suficiente para hablar serenamente de Senén, pues hemos sido colegas, cómplices y amigos, a lo largo de más de cincuenta años, ni tengo autoridad para escribir su vida, pero quiero aportar algunos datos, que ayuden a entender su trayectoria al servicio de la Palabra de Dios, ofreciendo así unas claves para entender su biografía. Fue un hombre entero, sin fisuras, historiador y analista literario, autor de una obra intensa de análisis, traducción y comentario del Nuevo Testamento. Nos hemos acompañado mutuamente, él no podrá completar la obra que había (que habíamos) proyectado; yo no me siento capaz de llenar el hueco que ha dejado en el estudio del cristianismo primitivo, pero quiero al menos comprender las claves de su biografía bíblica, ofreciendo algunos datos de su intensa trayectoria de investigador y, sobre todo, de su persona.

\section{UNOS DATOS DE SU VIDA, HASTA LA “RUPTURA” DEL AÑo 1984}

Habíamos nacido el mismo año (1941), y estudiamos juntos Teología en la Universidad Pontificia de Salamanca (1964-1965), pero apenas tuvimos ocasión de tratarnos, pues él seguía el plan académico ordinario, mientras que yo venía del Seminario Mercedario de Poio (Pontevedra), y sólo frecuenté en Salamanca unos cursos complementarios, licenciándome el año 1964 (él lo hizo el 1965), y quedé un año más, cursado las asignaturas de doctorando y defendiendo la tesis sobre Ricardo de San Víctor (1965), mientras él terminaba ese año su licencia. Los años siguientes nos encontramos en Roma (1966-1968), estudiando Sagrada Escritura en el Instituto Bíblico, donde nos licenciamos al año 1968, para separarnos después durante algún tiempo.

Yo empecé a enseñar teología en el Seminario Mercedarios de Poio (1969-1972) y presenté mi tesis doctoral en Filosofía (1971), mientras Senén siguió especializándose durante varios años en el "Colegio Español" de Múnich, donde ejerció labores de dirección (Dachauer Straße 19), profundizando en la mejor exégesis y teología bíblica y preparando su tesis doctoral, que presentó en la Universidad Pontificia de Salamanca, bajo la dirección del Prof. Felipe Fernández Ramos, el año 1979 sobre 
La Resurrección de Jesús en las Cartas de Pablo. Estudio de las tradiciones (BEB 50, Sígueme, Salamanca 1982).

Un año antes (durante el curso 1978-1979), él había dejado la dirección del Colegio Español de Múnich, para comenzar su enseñanza de Nuevo Testamento en el Estudio Teológico Agustiniano de Valladolid, donde ha sido después profesor por muchos años, tras "abandonar" la Universidad pontifica de Salamanca, el curso 1984-85 y después hasta su jubilación (19912014). Desde estas páginas, como estudioso de Biblia y amigo de Senén, quiero mostrar mi agradecimiento al Estudio Agustiniano de Valladolid, que ofreció a Senén una "casa" y un lugar de referencia, no sólo para enseñar en un contexto humanamente gratificante, sino para brindarle la mejor bibliografía para su estudios de especialidad.

Y así vuelvo a nuestro "camino compartido". Yo estaba enseñando en la Universidad Pontificia de Salamanca desde 1973, con la ingenuidad de los años jóvenes y de los buenos tiempos de la teología hispana, dedicado a diversos temas de espiritualidad, filosofía y Biblia (centrándome en especial en el Tratado de Dios Uno y Trino), pero no pude adquirir la preparación rigurosa y la precisión académica que ofrecieron a Senén los años de post-grado en Múnich, que culminaron como he dicho el año 1979, con la defensa de su tesis.

Esa fecha marcó un cambio intenso no sólo en el itinerario teológico y personal de Senén, destinado a enseñar Sagrada Escritura en su lugar natural (la Universidad Pontificia de Salamanca), sino también en mi propia forma de entender la teología bíblica y la docencia, pues encontré por primera (y quizá por última vez) un verdadero colega y amigo en el estudio de la Biblia. Senén era ya un maestro maduro, alguien que había comprendido y razonado las líneas básicas del movimiento cristiano primitivo, para fijar con rigor la historia de la vida y pensamiento de Jesús y de su movimiento primitivo, que desembocaba en Pablo y se extendía de formas nuevas en las diversas corrientes de la Iglesia. Yo había trabajado de manera más general, publicando lo que podía haber sido mi tesis doctoral bíblica (Los Orígenes de Jesús. Ensayo de Cristología Bíblica, Sígueme, Salamanca 1976; edición PDF en:

https://es.scribd.com/doc/199425099/Pikaza-Xabier-Los-Origenesde-Jesus); pero había preferido publicar ese libro como ensayo, para el diálogo y la investigación teológica, en comunicación con otros colegas.

Senén fue de los pocos que leyó de forma "crítica y creadora" ese "ensayo", aceptando en principio mi tesis de fondo, sobre la relación entre misterio de Dios e historia (nacimiento, vida y muerte de Jesús), y 
fijándose de un modo especial en algunos de mis análisis paulinos (1 Tes 1,9-10; Rom 1, 3-4...), que él retomó y profundizó en su tesis, cosa que he seguido agradeciéndole siempre. Y así comenzó nuestra verdadera amistad académica y se afianzó nuestra cercanía humana.

El curso siguiente (1980) empezó Senén a enseñar Nuevo Testamento (San Pablo) en la Pontificia de Salamanca, y fue como una luz nueva, una promesa de honestidad intelectual, de radicalidad analítica y de búsqueda del núcleo y raíz del cristianismo en la Universidad del Episcopado Español. Fueron, quizá, los mejores tiempos para la Teología de esa Universidad pontificia, desde 1980 hasta el 1984, año en que ambos tuvimos que dejarla, por motivos conectados. Fueron años de estudio intenso, proyectos y de logros muy significativos. Con cierta frecuencia nos juntábamos, tras las clases de la mañana, con Francisco Lanzac, director de publicaciones de Sígueme, en el Pato Rojo del Paseo de Carmelitas, para conversar sobre temas principales de la teología y de la vida de la Iglesia, desde una perspectiva de renovación bíblica. Éramos jóvenes, teníamos todo el futuro por delante.

Yo estaba menos seguro de lo que sería ese futuro, pues andaba trabajando en varios campos (filosofía, Biblia, Dogmática), pero él tenía ya claro su proyecto: preparar y publicar, de un modo riguroso, las tradiciones y textos del Nuevo Testamento, empezando por el desarrollo de la tradición de Pablo y después de los evangelios, no sólo para ofrecer a los lectores del lengua castellana un instrumento de base para el estudio histórico-crítico de la Biblia, sino para recrear desde sus cimientos la vida de la Iglesia, pasando así de una cristiandad sociológica de aldea (incluida la gran "aldea" de la estructura eclesiástica) a un evangelio que vinculara la fe de Pablo con el compromiso social de la tradición sinóptica.

Ciertamente, él conocía otras lecturas de la Biblia, de tipo legal y canónico, psicológico y antropológico, místico y eclesial, pero creía que los métodos histórico críticos, de corte diacrónico, con un exigente análisis textual, seguían siendo fundamentales, mostrándose en ese campo un heredero de la mejor exégesis alemana del siglo XIX y primera mitad del XX. Quería fijar el principio histórico de las tradiciones bíblicas, para seguir después su despliegue, y en esa línea estaba analizando día a día los textos del Nuevo Testamento, fascinando a los alumnos con su forma de recrear la vida de los primeros cristianos, fijándose de un modo especial en los escritos de Pablo y de su escuela. Fue un profesional de la Biblia, un investigador de cuerpo entero, siendo, al mismo tiempo, un hombre de Iglesia, al que he visto comprometido ofreciendo ejercicios 
espirituales a religiosas, cursos de renovación a militantes cristianos y acompañando a los marginados del entorno de la parroquia de San Pablo en Salamanca.

Senén se hallaba inmerso en la vida real, pero le importaba sobre todo el estudio de la Biblia y el contacto más hondo con sus alumnos, a lo largo de unas clases que eran ejercicios vivos de inmersión bíblica. Muchas veces discutíamos los temas de esas clases, que él me iba ofreciendo en fotocopia, como si pudiéramos trazar (cosa que en el fondo queríamos) un proyecto compartido de estudio bíblico-teológico de conjunto, desde la Universidad Pontificia de Salamanca. Lamento inmensamente haber perdido aquellos textos, traspapelados luego en varios cambios de domicilio.

Yo estaba más interesado por la teología de fondo de la Biblia, entendida como un camino abierto hacia la dogmática en general y hacia el pensamiento cristiano. Él pensaba que era más urgente empezar analizando los textos concretos de la Biblia, como muestran, por ejemplo, los trabajos que publicamos en el homenaje de la Universidad Pontificia al que había sido su Rector Magnífico: Quare Paulum. Miscelánea homenaje a Mons. Dr. Lorenzo Turrado, Universidad Pontificia, Salamanca 1981.

Senén publicó un estudio extraordinario sobre Flp. 2, 6-11. Su lugar teológico (págs. 149-181) analizando el origen y sentido básico del himno, en una línea histórica (es decir, desde el lugar humano de Jesús de Nazaret como mesías crucificado, y no desde un hijo pre-existente de Dios, "antes" o por encima de la encarnación). Yo, en cambio, escribí un trabajo sobre Conocimiento de Dios y juicio escatológico en Rom 1, 18-3, 20 (págs. 119-147) en el que, más que el origen y análisis histórico-literario del texto, me interesaba su aportación en la línea de la teodicea cristiana. Ambos buscábamos, de maneras complementarias, una renovación del pensamiento y de la vida de la Iglesia desde el estudio de la Biblia, en el lugar que entonces parecía más apropiado: La Universidad Pontificia de Salamanca.

Así fueron pasando esos años (1979-1984), que considero hoy felices, Senén con los Operarios Diocesanos, yo con los Mercedarios, ambos en una Facultad de Teología donde se podía respirar en libertad. Él preparaba día a día su análisis de las tradiciones y del texto del Nuevo Testamento. Yo me ocupaba básicamente de una gran teodicea cristiana, como indicaba mi libro Experiencia religiosa y Cristianismo (Sígueme, Salamanca 1981), mientras iba escribiendo una tesis doctoral en Sagrada 
Escritura sobre Mt 25,31-46, que quería presentar en el Bíblico de Roma a finales del año 1984.

Hicimos cosas que entonces nos parecían sencillas, pero que hoy veo como extraordinarias. Dirigimos tesis doctorales, asistimos a congresos tanto en España como en Alemania, preparábamos proyectos compartidos... Pero nuestras trayectorias cambiaron de rumbo, casi de repente, por imposición externa, en la Universidad Pontificia, y tuvimos que abandonar la enseñanza activa y, así, sin haberlo previsto con antelación, nos vimos abandonados a nuestra propia suerte. Habían venido nuevos profesores, otros cambiaron su forma de pensar y de situarse ante el cristianismo, pues empezaron a soplar vientos distintos en el "espíritu" posconciliar de la Iglesia, y no quedó demasiado espacio libre para personas como Senén Vidal en la Universidad del Episcopado Español. Como he dicho ya, no pretendo mostrarme imparcial, pues soy parte interesada de esa historia (y de la salida de Senén), pero no tengo más opción que contarla desde mi perspectiva.

Por "influjo" de algunos profesores de la Facultad de Teología y quizá por presiones de la Congregación de Seminarios y Universidades de Roma, al terminar el curso 1983/1984, a Senén le pusieron dificultades para seguir enseñando, y a mí me negaron el Nihil Obstat preceptivo, de manera que tuve que abandonar la cátedra durante varios años, pudiendo volver sólo en condiciones nuevas (bajo prohibición de enseñar materias dogmáticas) el año 1989. Pues bien, en ese contexto, el Rector de la Pontificia (el Dr. Luis Acebal, q.e.p.d.), movido por presiones de "colegas" de la casa, quiso imponer sobre Senén algunas condiciones que él juzgo inaceptables, de manera que (por coherencia y honestidad intelectual) no tuvo más opción que renunciar a la enseñanza.

Las razones de su "cese" (en otro lenguaje: de su "marcha") fueron variadas, y algunos "supervivientes" de aquel fatídico 1984 (pasados 33 años) podrán contar la "feria" de otra forma (una historia que no se encuentra escrita, sino hablada y decidida en conventículos y grupos de presión), pero entre los motivos de su "cese" estaba su manera de enseñar teología desde Pablo y también (al menos de un modo colateral) su forma de situarse (y protestar) frente a mi "caso" (es decir, frente al hecho de que me negaran el nihil obstat).

Como he dicho, seguramente, no hay "papeles" de todo aquello (o al menos yo no los conozco), pues las cosas se decidieron entre pasillos y reuniones "particulares", sin que hubiera (sin que tengamos todavía) una prueba documentada y legal del proceso. Mi caso era más claro: Había 
enseñado cosas que parecían poco "ortodoxas” y me tenía que ir, sí o sí. Pero el suyo se podría haber resuelto quizá de otra manera. En ese contexto le insistí en que no fuera "extremado", que se doblara políticamente a las presiones, que aceptara las propuestas que le hacían, que siguiera en la Pontificia, que los alumnos le necesitaban ( ¡y cómo le han necesitado después!), que yo volvería, que reiniciaríamos nuestra "marcha" por la teología.

Pero no quiso; no pudo, por honradez y coherencia personal, quizá porque vio mejor las cosas, era un hombre clarividente, aunque (¡o quizá por ello!) de carácter recio. Pensó que no podía ni debía doblegarse, y a pesar de mi insistencia me acabó diciendo: ¡Si no te dejan enseñar a ti, esos que bien sabes, yo no puedo seguir enseñando en su Universidad! Y así se fue (así nos fuimos), así le "echaron" de la Pontificia de Salamanca, un triste 1984, en pleno período de madurez.

Nos separamos con gran tristeza. Yo anduve por ahí dando vueltas, durante mucho tiempo, hasta que volví a la Pontificia, bajo nuevas condiciones, desde el 1989 hasta el 2013. Senén no quiso volver, ni entrar físicamente en la "casa", ni siquiera en la biblioteca, ni para una tesis doctoral. Así me dijo: "Con las personas, una a una, me seguiré tratando, como cristiano. Con la institución no puedo pactar, como quieres que lo haga...". Y no volvió a entrar ni en el gran edificio de la Clerecía (la Pontificia) con gran pérdida para la casa y sus alumnos, no entró ni siquiera en su biblioteca, pues me dijo: ¡Es mejor la de Valladolid, y no tengo que andar bajando la cabeza!

De esa manera conservó y mantuvo su libertad, al servicio de la Sagrada Escritura, enseñando básicamente en el Instituto Teológico Agustiniano de Valladolid (1974-1985 y 1991-2014), hasta su jubilación, y en varios centros universitarios de América, Washington (1985-1987), Universidad Pontificia de México, Seminario San Carlos y San Ambrosio de La Habana, Facultad de Teología de Lima, guiado siempre por su proyecto de publicar una edición rigurosa de las tradiciones y libros del Nuevo Testamento, fijándose especialmente en la vida de Jesús y en las cartas de Pablo.

Estuvimos unos años sin vernos (del 1984 al 1989), cada uno por su lado, pero sabiendo que seguíamos firmes en lo nuestro, que el trabajo principal seguía, y él iba avanzando en el suyo (cosa que hizo de un modo ejemplar, como seguiré indicando), y yo iba buscando la dirección de mi propuesta teológica. Desde entonces, dos o tres veces al año, nos hemos visto, hemos conversado a lo largo de una tarde, nos hemos ayudado a 
situarnos ante el gran misterio del Dios de la revelación cristiana. Especialmente significativos fueron nuestros encuentros del año 2010 al 2012, cuando yo estaba preparando mi comentario al Evangelio de Marcos. La Buena Noticia de Jesús (Verbo Divino, Estella 2012).

Con esa ocasión hicimos una especie de pacto implícito. Él publicaría los textos del Nuevo Testamento, con un análisis muy concreto de tipo histórico-literario, yo los comentaría de un modo más teológico. Así trabajaríamos desde perspectivas distintas pero convergentes. En esa línea seguía yo investigando sobre el Evangelio de Mateo, hace un año y tenía el comentario prácticamente terminado el día de su muerte (saldrá publicado en Verbo Divino, Estella, este año 2017). Habíamos quedado en hablar sobre el tema, en precisar algunos detalles, relacionados sobre todo con la vinculación de Mateo con la tradición de Pablo (especialmente con Efesios) pero no pudo ser. Le sorprendió la muerte a plena luz de día, calzadas las botas en línea de evangelio.

\section{Punto de partida, el área de Pablo}

En ese contexto, pasado casi un año de su muerte, me atrevo a presentar una semblanza básica de su obra, como si fuera mía, porque, de hecho, es una parte de mi vida y de mis publicaciones. He comentado ya su primera, quizá la más provocadora, su tesis doctoral, titulada La resurrección de Jesús en las cartas de Pablo. Análisis de las tradiciones (Sígueme, Salamanca 1982). En ella sobresalían aportaciones fundamentales. (a) El estudio de las primeras tradiciones cristianas, centradas básicamente en la confesión pascual de la Iglesia. En el principio del movimiento cristiano estrictamente dicho, tal como lo ha puesto de relieve la comunidad helenista prepaulina, no se encuentra la posible vida mesiánica de Jesús, sino la confesión pascual de las comunidades. (b) Pero esa confesión pascual, cerrada en sí misma, corría el riesgo de diluirse, a no ser que se integrara en una visión teológica de fondo y en un movimiento eclesial bien integrado, con vocación de independencia, en la línea de la renovación y cumplimiento de la promesa de Israel, como fue el movimiento y teología de Pablo.

A partir de ese supuesto, Senén ha querido analizar de un modo minucioso las cartas originales de Pablo, distinguiendo en ellas tres estratos: las tradiciones previas de la Iglesia helenista, la aportación del mismo Pablo y la redacción eclesial posterior. Fruto de ese análisis y estudio fue 
una obra de gran calado que lleva el título de Las cartas originales de Pablo (Trotta, Madrid 1996), donde analiza y recoge las cartas auténticas del apóstol, tal como han sido asumidas, completadas y organizadas por la tradición posterior, hasta desembocar en el orden actual del Corpus Paulino (donde han sido incluidas también otras cartas escritas a nombre de Pablo por sus discípulos continuadores).

Se trataba de una obra magistral, escrita con los mejores métodos de la crítica histórico-literaria, con una traducción transparente del texto, distinguiendo con lógica implacable sus diversos estratos. (a) Las tradiciones prepaulinas, que provienen básicamente de las Iglesias helenistas en las que se integró Pablo (primero en Damasco, luego en Antioquía). En ese contexto, Senén dijo las cosas fundamentales que pueden decirse, aunque le faltaba analizar la relación entre las tradiciones prepaulinas y las del documento Q y de los sinópticos. (b) La elaboración propia de Pablo, realizada básicamente tras su "ruptura" con la iglesia de Antioquía (58/59), a lo largo de su misión autónoma, tal se expresa en las cartas auténticas (1Tes, Gal,1-2 Cor, Flp, Fl y Rom), que recogen y exponen el proyecto mesiánico de Pablo. (c) La elaboración postpaulina que ha procurado no sólo recrear unitariamente esas cartas, a partir de materiales previos, sino introducir en ellas una serie de anotaciones y glosas, que permitan no sólo su conservación (en el corpus paulino), sino su aceptación como elemento central de la vida de las iglesias.

Para publicar esta obra, que sería el punto de partida de su nueva producción teológica, Senén Vidal escogió una editorial de gran prestigio técnico y social, como era Trotta, dirigida por su colega y amigo Alejandro Sierra, pensando que ella podría ser la promotora de su proyecto de "refundación bíblica cristiana". La edición fue esmerada, la tipografía perfecta, pero el gran mundo intelectual hispano no estaba preparado para una obra como aquella, que corrió el riesgo de caer en el olvido, no sólo por su carácter científico, sino porque el editor no se atrevió a apostar por ella, acogiendo en su catálogo la producción bíblica completa de Senén.

El problema no fue de Senén, ni quizá tampoco de la Editorial Trotta, sino del contexto cultural hispano. (a) Por un lado, la sociedad civil, cada vez más alejada de la tradición cristiana, no se interesó por la obra de Senén, ni por su visión de Pablo, precisamente por su rigor científico y por su identidad cristiana, y quizá porque no daba lugar al escándalo eclesial, ni a la crítica fácil contra el cristianismo o la iglesia, cosas que siguen siendo preferidas en muchos círculos de poder de la cultura. (b) 
Por otro lado, la Iglesia oficial hispana (e hispano-americana), inmersa en el miedo del post- o casi anti-concilio Vaticano II no podía admitir ni potenciar una obra sanamente crítica como la de Senén, de manera que no podía aceptarla como punto de partida de una renovación cristiana.

Éste ha sido el destino de la obra de Senén, y de otros pensadores cristianos, celosos de su independencia crítica y de su fe evangélica, entre una sociedad falsamente laica que rechaza el cristianismo y una Iglesia oficial que desconfía de la libertad de pensamiento. Por su parte, los colegas biblistas se hallaban empeñados en otras batallas, que podían ser también importantes, pero que no iban en la línea de lo que intentaba Senén, de manera que le dejaron casi a solas con su proyecto bíblico.

En ese contexto, algunos de sus amigos le dijimos que quizá debía fundamentar y presentar de un modo más unitario su visión de Pablo, para que pudiéramos situar su obra de un modo más preciso en el origen de la Iglesia, explicando con claridad su despliegue y sus aportaciones, en diálogo con otros exegetas, pues en la obra anterior (Las Cartas Originales de Pablo) él había renunciado a todo diálogo externo, diciendo que los expertos no necesitaban más referencias bibliográficas, y que los no expertos no las entenderían. De todas formas, en algún sentido, nos hizo caso, y así vino a publicar su obra clave, en su misma "casa" (Sígueme, Salamanca: de los Operarios Diocesanos), una obra espléndida titulada El proyecto mesiánico de Pablo (Sígueme, Salamanca 2005).

Ésta fue y sigue siendo una obra trascendental dentro del panorama bíblico español (y de la cultura de lengua castellana), el primer libro en el que se aborda de un modo científico y "escolar", académico y abierto a todos los lectores la experiencia de Pablo y su proyecto mesiánico (es decir, su visión de la obra de Jesús), que está en la base de todo el cristianismo posterior. Fue una aportación revolucionaria, en el mejor sentido de la palabra, renovadora y tradicional, una obra clave para entender el principio del cristianismo.

A partir de esa obra, y de las dos anteriores publicadas en Sígueme (Los escritos originales de la comunidad del discípulo amigo de Jesús, El evangelio y las cartas de Juan, 1997; Los tres proyectos de Jesús y el cristianismo naciente (2003), con la edición y comentario de Filón de Alejandría (Los terapeutas. De vita contemplativa, 2005) y de 1 Tes (El primer escrito cristiano: Texto bilingüe de 1 Tesalonicenses con introducción y comentario, 2006 ), Senén podía haber programado y editado de un modo unitario su proyecto bíblico en su editorial Sígueme, de Salamanca (con sus hermanos, los Operarios Diocesanos). Pero hubo algo que le hizo 
desistir, pues descubrió que esa Editorial, que era de su familia religiosa (Sígueme), se estaba escorando en una línea buena, pero distinta de la suya, y así buscó y encontró en Valladolid (¡su lugar de enseñanza básica!) otra editorial que respondiera plenamente a su proyecto y que garantizara la publicación del conjunto de su obra: Ediciones Sal-Terrae, (bajo la dirección de su discípulo y amigo: Ramón Alfonso Díez). Así surgió por entonces (año 2006/2007) el proyecto de publicación de conjunto de la obra de Senén en Sal-Terrae o, mejor dicho, en el Grupo Editorial Loyola, en el se incluye también la editorial Mensajero).

En este contexto se inscribe la reelaboración de una obra anterior, publicada en Sígueme (El proyecto mesiánico de Pablo (Salamanca 2005), de manera más académica y técnica. Como signo de confianza con su nueva editorial, Senén reelaboró la obra anterior de Sígueme, presentándola por una parte de manera más sencilla (de lectura más fácil) y por otro mas universal (abierta a una comprensión de conjunto del cristianismo) con el título de Pablo. De Tarso a Roma, publicándola ya en SalTerrae (Santander 2007). Fue una reelaboración de gran éxito, y Senén se encontró por fin a sí mismo, en su nueva editorial, descubriendo y trazando lo que sería el camino de conjunto de su obra. En esa línea, S. Vidal pudo condensar y sistematizar su visión de Pablo en una obra menor, dedicada al gran público, con el título de Iniciación a Pablo, San Terrae, Santander 2008.

Con esa ocasión nos encontramos, y volvimos a revisar y compaginar nuestros proyectos de estudio y publicación, que debían desembocar en una obra general sobre los orígenes del cristianismo, que ambos estábamos preparando, y que quizá se podría convertir en publicación compartida, aunque quizá faltaban varios años de preparación para realizarla. En ese contexto se sitúan sus tres obras finales sobre Pablo. La primera y más importante se titula Las Cartas Auténticas de Pablo (Mensajero/Loyola, Bilbao 2012, del grupo editorial al que pertenece Sal-Terrae). Es una obra impresionante de síntesis y maduración, que recoge y reelabora de un modo total la anterior (Las Cartas Originales de Pablo, Trota Madrid 1996), con texto griego, introducciones y notas, el estudio más importante que existe en castellano sobre el origen, sentido y desarrollo de los escritos de Pablo, una obra definitiva en su campo, que será difícilmente superada en los próximos decenios.

En ese contexto, con el fin de preparar la edición y comentario completo del Corpus Paulino, le pedí que empezara escribiendo una obra sobre Colosenses y Efesios, para la colección de "Guías de lectura del 
Nuevo Testamento", que Mercedes Navarro y un servidor estábamos publicando en Verbo Divino, Estella. Por pura amistad, a pesar de sus ocupaciones, accedió y preparó un libro precioso titulado Colosenses y Efesios, GLNT, Verbo Divino, Estella 2013, demostrando con rigor que estas cartas no son auténticas de Pablo, sino que reflejan la vida y la problemática de unas comunidades paulinas de finales del siglo I y comienzos del siglo II en la región de Asia Menor.

Con ese fin, en la primera parte del libro, Senén analiza el contexto histórico, literario y teológico de esos "escritos", para situarlo dentro del despliegue de la tradición paulina, procurando que la traducción castellana sea lo más cercana posible al original griego, para poder recuperar así la frescura y el impacto del texto antiguo, que fue escrito para ser leído y proclamado en un contexto comunitario. El comentario al texto se hace por medio de introducciones a las diferentes secciones, de un carácter más general, y por medio de observaciones cercanas al texto, de un tono más concreto. Todas ellas están redactadas en un estilo concentrado, intentando recoger en el menor espacio posible los datos claves para la comprensión del texto. De este modo, estas dos partes del libro quieren ser la guía inmediata de una lectura detenida de los escritos.

Y de esa forma termina el área de Pablo, que había empezado con la tesis doctoral (sobre La resurrección de Jesús en las cartas de Pablo, Sígueme, Salamanca 1982) y que se abre (o se cierra), significativamente con otro libro dedicado a la resurrección, publicado precisamente en los últimos días de la vida de Senén: La resurrección de los muertos. El testimonio bíblico, Sal Terrae, Santander 2016. Éste es en el fondo un "libro testamento", sobre el que habíamos dialogado con cierto detalle, partiendo de nuestro reencuentro (año 1979).

Se trata de una reelaboración de su tesis doctoral (La resurrección de Jesús en la cartas de Pablo, 1982), pero con dos aportaciones fundamentales. (a) Senén resitúa el testimonio eclesial (paulino) de la resurrección situándolo en el contesto del mensaje de Jesús, que "proclamaba y escenificaba" el acontecimiento del Reino, desde una perspectiva de esperanza en la resurrección. De esa manera recupera desde la confesión de fe paulina (de la Iglesia) la experiencia histórica de Jesús, tal como culmina en su muerte. (b) En un segundo momento, Senén interpreta y desarrolla la experiencia pascual de Jesús desde la perspectiva de la inauguración de la época mesiánica, con la esperanza de la nueva creación, como obra definitiva de Dios, recuperando así, desde la cristología ecle- 
sial, la más honda fe teológica (bíblica) en el Dios que crea las cosas de la nada y que resucita a los muertos de la tumba.

\section{III. Área de Jesús. El CENTRo de SU VIDA}

Muchas veces habíamos tratado de la auténtica "novedad cristiana", que se centra en el Dios que crea y resucita a los muertos, para recuperar así, desde Jesús, la experiencia más honda de Israel, en el testimonio del Dios de la vida. De eso íbamos a tratar, en el tiempo de pascua del año pasado (2016), retomando el argumento de nuestras primeras conversaciones teológicas (de 1980 a 1984) desde el tema de la pascua de Jesús. Pero no pudo entregarme ese libro (La Resurrección de Jesús, 2016) en mano, no pudimos sopesar sus argumentos, pues el Dios de Jesús le acogió en su seno, un 11 del 4 del 2016), en el camino hacia su casa, mientras venía de celebrar la Pascua de Jesús en la eucaristía

La vida académica de Senén había estado más centrada en el mensaje y obra de San Pablo, pero su intención fundamental era el estudio de Jesús, es decir, la identidad de aquel a quien Dios había resucitado de la muerte, constituyéndole Cristo y Señor. Ésta fue su tarea más honda, su labor más intensa, partiendo del mensaje y de la historia de la Biblia (de la Iglesia primitiva) y no desde un tipo de dogmática posterior, de carácter doctrinal, que parte de la existencia de un Hijo Eterno de Dios, independiente de la encarnación. De esa forma vino del mensaje pascual de Pablo a la historia de Jesús, haciendo el camino del Nuevo Testamento (que pasa de Pablo a la vida de Jesús, y no a la inversa).

He sido un testigo de que ese "proceso" largo, que le permitió pasar del testimonio paulino de la resurrección del Cristo a la vida histórica del Jesús resucitado, rehaciendo así, de un modo personal, gozado y sufrido, el mismo camino de la iglesia antigua, que sólo pudo escribir y escribió los evangelios sinópticos y especialmente el de Juan en un momento posterior, después que se había extendido básicamente el mensaje de Pablo. Fue un proceso largo, que tuvo algo de "revelación", es decir, de descubrimiento personal, fundado no sólo en el estudio de unos textos exteriores, sino en el re-conocimiento y despliegue de su propia experiencia creyente, vinculada a la de Jesús, con sus tres momentos principales, que él pudo fijar, de un modo magistral, en su obra quizá más significativa, una obra que fue para él una especie de "revelación", como decía a sus ami- 
gos: Los tres proyectos de Jesús y el cristianismo naciente, Sígueme, Salamanca 2003.

En un primer momento, la tesis del libro parece objetivamente clara, pues distingue y vincula en la vida de Jesús tres momentos principales. 1. Jesús fue profeta apocalíptico, como Juan Bautista (siendo discípulo y colaborador suyo). 2. Fue después mensajero del Reino de Dios en su etapa galilea. 3. Finalmente ha venido a mostrarse como Mesías que sube a Jerusalén para instaurar el Reino, estando dispuesto a ser crucificado (y siéndolo de hecho, descubriendo que su muerte forma parte de la venida del Reino). Pero, en el fondo, esa tesis describe no sólo el despliegue del proyecto y vida histórica de Jesús, sino que vincula esa vida (por su última etapa) con la confesión de fe de la Iglesia.

S. Vidal no quiso ofrecer en este libro una «biografía» de Jesús, sino tres «retratos» en los que se expresan los momentos básicos de su vida y movimiento, dentro del contexto judío de su tiempo, desde la perspectiva de la instauración del Reino de Dios, que se identifica en el fondo con su propia obra mesiánica. La tesis de S. Vidal se parece en un primer momento a la que había propuesto A. Schweitzer, hablando primero de una etapa Galilea de Jesús (terminada en el fracaso), para detenerse en la etapa jerosolimitana, también culminada en el fracaso. Pero Senén Vidal habla de tres etapas, y no de dos (como Schweitzer), con un fracaso final del que nace la Iglesia. Habla de tres etapas, que se vinculan entre sí y que se abren, a través de la tercera (la entrega pascual de Jesús en manos de Dios), a la tarea y misterio pascual de la Iglesia.

Ciertamente, con gran parte de la crítica actual de los evangelios, Vidal aceptaba el supuesto básico de la investigación K. L. Schmidt (Der Rahmen der Geschichte Jesu, 1919), quien afirmaba que el esquema básico (geográfico y cronológico) de los evangelios era producto de los mismos redactores, de manera que no podemos distinguir con precisión (de un modo textual) los momentos y límites del proceso biográfico de Jesús. Pero, admitido eso, él afirma (y muestra) que el proyecto biográfico (de Reino) de Jesús incluye tres momentos, que pueden y deben distinguirse con cierta precisión, un proceso cuya trama él fue descubriendo no sólo a través del estudio de los textos, sino a través de una especie de "iluminación interior" que marcó los últimos años de su vida.

1. En un primer momento, como buen israelita, Jesús fue un "profeta bautista", un mensajero escatológico de conversión, lo mismo que Juan (llamado el Bautista), con quien convivió durante un tiempo, siendo bau- 
tizado por él y actuando después como discípulo y colaborador suyo. Éste es un dato que ha solido pasarse de largo, pero que ha sido bien atestiguado por el evangelio de Juan (cf. Jn 1-4), a pesar de la dificultad que ello implicaba para los mismos cristianos. Durante un tiempo, Jesús compartió el mensaje y proyecto del Bautista, que predicaba la conversión, ofrecía el bautismo como signo de perdón y anunciaba la llegada del juicio de Dios (y la presencia-actuación de uno "más fuerte").

De esa manera retomó Jesús el mejor proyecto profético-penitencial de su pueblo. Durante un tiempo, él estuvo convencido de la gravedad de los pecados del pueblo, que no podían perdonarse a través de los sacrificios del templo, sino sólo por medio del arrepentimiento y del bautismo en el Jordán, hasta el momento en que llegara el juicio de Dios, y pudiera comenzar la nueva etapa, que vendría definida por la instauración del Reino en este mismo mundo. Eso significa que Jesús no sólo fue discípulo de Juan Bautista (recibiendo su bautismo), sino que compartió por un tiempo su proyecto penitencial-bautista, presentándose como pecador ante el juicio de Dios que llega, con el resto de los pecadores "arrepentidos" de Israel.

Los elementos básicos del mensaje del Bautista han seguido influyendo en el proyecto posterior de Jesús, pero de una forma nueva, reinterpretados desde su nueva experiencia y tarea de Reino. Eso significa que él, Jesús, fue cambiando de proyecto, en obediencia a Dios, en un proceso impresionante de fidelidad profético-mesiánica, que le ha hecho recorrer y recrear los momentos principales de la historia israelita, según aquel principio de la "identidad" entre filogénesis y ontogénesis. Jesús no nació ya formado y completo del Padre Zeus, como la diosa del mito griego, sino que se fue formando, en humanidad y encuentro con Dios, conforme al principio esencial del Concilio de Calcedonia (451). La historia mesiánica de la Navidad (narrada por Mt 1-2 y Lc 1-2) forma parte de la fe pascual de la Iglesia, que ha proyectado su fe en el comienzo de la vida de Jesús. Pero de hecho, el principio del evangelio de Jesús fue el mensaje y camino del Bautista (como dice de manera programática Mc 1, 1-2).

2. Jesús fue profeta escatológico, mensajero del Reino de Dios en Galilea. En un momento dado, quizá tras la entrega y prendimiento (muerte) de Juan Bautista, Jesús tuvo una experiencia nueva de Dios, que Mc 1, 9-11, sitúa "después" de su bautismo en el Jordán (tras el mensaje y camino del Bautista), descubriendo así que el "tiempo" de Dios 
había cambiado, es decir, se había acelerado, de forma que él no podía ya impartir el bautismo de conversión, anunciando la llegada del juicio, para que después viniera el Reino, pues había llegado el tiempo de anunciar e iniciar directamente el Reino en su propia tierra (en Galilea).

Este primer paso (del Jordán y del desierto a Galilea), del agua penitencial al mensaje del Reino, determina desde ahora toda la historia de Jesús, que descubre y proclama el nuevo plan de Dios, su esencia más profunda. (a) En este momento, Jesús ya no nos lleva de la conversiónbautismo en el Jordán, a través del juicio de Dios, a la entrada en la tierra prometida, como pensaba Juan Bautista. (b) Dios ha empezado ofreciendo ya gratuitamente el Reino, como don de vida y perdón, sin necesidad de conversión anterior, pues la conversión y el cambio de vida vendrá después, como efecto del don recibido del Reino (como supone Mc 1,1415).

Por eso, durante un tiempo (entre uno y tres años), Jesús actuó como mensajero "aldeano" (la palabra aldeano le gusta a Senén más que la de "campesino") del Reino de Dios en Galilea. Dejó de impartir el bautismo y de anunciar directamente el juicio, para proclamar y escenificar, de un modo sacramental y social, la llegada del Reino de Dios, empezando desde los más pobres. De esa forma actuó como profeta aldeano, para los labradores, pastores y pescadores de Galilea, pensando que ellos se "convertirían", aceptando su mensaje, para subir con él a Jerusalén, donde se iniciaría el Reino final.

En este momento de su mensaje en Galilea, Jesús se seguía presentando básicamente como profeta del Reino (no como mesías), como profeta mesiánico que anuncia el mensaje de Dios (¡Llega el Reino!), impartiendo una enseñanza centrada en el amor y el perdón de Dios, y en la exigencia de comunión entre los marginados de Galilea. No proclama la llegada de un Reino trascendente (para después, al final del mundo), sino que anuncia y prepara la venida (instauración) del Reino Histórico de Dios, en la misma tierra de Galilea, transformando gradualmente la vida de los hombres, a partir de los campesinos y marginados a quienes se dirige, empezando por los excluidos, marginados, pobres y pecadores de aquel duro contexto israelita.

De esta forma resuelve S. Vidal la oposición que tantas veces se ha puesto de relieve entre la visión del Reino de Dios como Presente y su llegada como Futuro. A su juicio, el Reino es el presente de Dios que actúa, es un proceso de transformación de las condiciones de vida personal y social de los galileos, según la voluntad de Dios, de un modo inte- 
gral, personal y comunitario, económico, espiritual y social. En ese sentido (en contra de una lectura defectuosa de una palabra de Jesús en el juicio ante Pilato, según Jn 18, 36), en aquel momento, Jesús concebía el Reino de Dios como una transformación radical de las condiciones de vida de este mundo, de forma que viene a través de una elevación (de una recreación) de la vida social y personal de los judíos galileos, desde la vida de las aldeas (no desde el templo de Jerusalén, como querían los sacerdotes), en gesto de transformación de gracia (no por ley, como querían los proto-fariseos).

3. Jesús actuó y murió, finalmente, como Mesías regio (davídico) en Jerusalén. Normalmente, él debería haber subido a la ciudad del templo, después de haber culminado su mensaje en Galilea, acompañado por los campesinos convertidos (por la casi totalidad de los galileos), para instaurar el Reino en la ciudad de David. Pero su mensaje en Galilea fracasó, al menos en un sentido (como había fracasado el de Juan Bautista en el Jordán), o, mejor dicho, se mostró insuficiente, pues la mayoría de los campesinos de su tierra no se convirtieron, ni aceptaron su propuesta de Reino. Además, los mismos que persiguieron y lograron que Herodes Antipas matara a Juan Bautista, amenazaron a Jesús: Los "notables" de la administración de Herodes, los responsables de la nueva economía, los delegados del judaísmo sagrado (del templo) y de las nuevas tendencias nacionales que desembocarían en el rabinismo posterior persiguieron a Jesús en Galilea.

A pesar de ello (o, mejor dicho, por ello), Jesús tuvo el convencimiento de que debía adelantarse la venida del Reino de Dios, y por eso subió a Jerusalén para anunciar su llegada, y empezó a comportarse ya como Mesías real (davídico) y no como simple profeta (como había hecho antes en Galilea). Su rechazo (su fracaso relativo) en Galilea había sido un signo de que se abría un tiempo nuevo (el tiempo mesiánico), de forma que él debía recoger-culminar su mensaje anterior, para presentarlo y presentarse en Jerusalén, como Rey Davídico, para instaurar el Reino de Dios, un Reino que seguía teniendo rasgos de "aldea", es decir, de comunicación directa entre los pobres y marginados, en contra de las tendencias sacrales e imperiales de Jerusalén (con el Templo de lo sacerdotes, con los delegados del Imperio de Roma).

Este paso clave de la vida de Jesús, de profeta del Reino (Galilea) a mesías regio (Jerusalén) está determinado por la misma dinámica del Reino, es decir, por la actuación del Dios Liberador de la tradición israe- 
lita en cuyo nombre él actuaba. Pues bien, también ahora, en un primer momento, Jesús pudo pensar y pensó que los habitantes de Jerusalén podrían convertirse, acogiendo el Reino de Dios (empezando por los mismos sacerdotes del templo). Pero, al ver que no le recibían, él descubrió de hecho que tendría que entregar su vida por la llegada del Reino, interpretando su muerte en forma de "don" o regalo para el Reino, no como sacrificio expiatorio, en la línea de gran parte de los sacrificios del templo de Jerusalén, sino como don o regalo de Dios para los hombres, empezando por los de Jerusalén.

Ciertamente, Jesús contó hasta el final con la posibilidad de una intervención superior de Dios, aunque no en línea de milagro externo (como otros profetas de "signos", que anunciaban acciones portentosas de Dios, en el río Jordán, en el Monte de los Olivos o en el mismo templo). Pero, de manera cada vez más intensa, él fue descubriendo que Dios no actuaría de una forma externa (destruyendo las murallas de Jerusalén, matando a los romanos, derribando materialmente el templo), sino a través de la entrega voluntaria de la vida, empezando por él, que debía mostrarse dispuesto a morir al servicio del Reino.

Pues bien, a pesar de todo eso (o quizá mejor por eso mismo) Jesús se entregó a la muerte, como indican las palabras de la Última Cena, y de esa forma murió confiando en la llegada del Reino de Dios (como supone Mc 14,25), sabiendo que su muerte, su fracaso externo, era una garantía y señal de la llegada del Reino, como la Iglesia posterior ha confesado en su fe pascual. De esa forma descubrió, al borde de su muerte, que su misma vida estaba vinculada a la llegada del Reino, no como sacrificio de expiación (por los pecados del mundo, ante la ira de Dios), sino todo lo contrario: Para expresar la generosidad de Dios, que ama y perdona a los hombres precisamente allí donde ellos matan a los justos. De esa manera, como expresión intensa del amor de Dios (en gesto de amor, en medio del dolor natural) se entregó Jesús a la muerte, esperando la llegada del Reino, en forma de Resurrección.

Senén no quiso ofrecer una «biografía» de Jesús, en el sentido moderno del término (como despliegue de su auto-conciencia o como expresión de un desarrollo psicológico de su personalidad), sino que ha descubierto y fijado con precisión los tres momentos fundamentales de su vida y movimiento, en un proceso que va del contexto judío de aquel tiempo (primer momento, con Juan Bautista), a través de su propia conciencia mesiánica (mensaje de Reino en Galilea), hasta el descubrimiento del sentido y aportación de su muerte a la llegada del Reino, en una línea que será retomada 
y desarrollada dramáticamente por los primeros cristianos helenistas y $\mathrm{Pa}$ blo, cuando afirmen que Dios le ha resucitado de la muerte, iniciando de esa forma el Reino, en forma de resurrección.

Ésta ha sido quizá la aportación histórico-teológica más importante de S. Vidal, que se ha atrevido a fijar los momentos del despliegue de la "conciencia y obra" mesiánica de Jesús. (a) En un sentido, esta obra ofrece un punto de llegada y un compendio de los mejores trabajos que se han pensado y escrito sobre la vida y obra de Jesús en los últimos decenios. (b) Pues bien, al mismo tiempo, esta obra puede y debe tomarse como un punto de partida para entender no sólo el despliegue y permanencia del proyecto de Jesús (a partir de su tercer momento), sino la obra teológica del mismo Senén Vidal, que ha tenido el atrevimiento de introducirse en la dinámica del pensamiento y de la obra profético-mesiánica de Jesús, a quien mira siempre desde la perspectiva del Dios que actúa (que promete e instaura su Reino) y desde la perspectiva del mismo Jesús histórico, que abre y encarna el camino de Dios en la historia.

Éste ha sido el descubrimiento (el cambio mayor) en la obra bíblico/teológica de S. Vidal, que le ha permitido vincular el mensaje de Pablo con la experiencia y mensaje (con la muerte) del Jesús histórico, uniendo así los dos elementos fundamentales de la novedad cristiana, que no son la historia de Jesús y la "transcendencia eterna del Hijo de Dios" (como en el pensamiento clásico de los concilios: Credo de Nicea-Constantinopla-Calcedonia), sino la historia de Jesús (con su muerte) y el mensaje de la resurrección. De esa manera resitúa S. Vidal toda la tradición teológica de la Iglesia, sustituyendo el paradigma ontológico de la formulación de los grandes concilios (de Nicea a Calcedonia), por un paradigma histórico, centrado en el Dios de la Biblia.

Así lo fijó S. Vidal, tres años más tarde, de un modo ya definitivo, cuando rehízo la obra anterior (Los tres proyectos, Sígueme, Salamanca, 2003) en un nuevo libro en el que resume y profundiza su visión de Jesús: Jesús, el Galileo, Sal Terrae, Santander 2006. Con esto quedó fijado, diez años antes de su muerte, su cambio "teológico" decisivo, y su nueva orientación editorial, que estará vinculada en el futuro a Sal-Terrae/Mensajero (del grupo Loyola), donde publicará todas sus obras (a excepción de Colosenses-Efesios, que me entregó, como favor personal, para mi colección de GLT: Verbo-Divino, Estella 2013). Desde este momento, S. Vidal pudo vincular toda su obra al despliegue unitario de su visión de Jesús, como hizo en uno de sus últimos libros, en el que ofrece un esque- 
ma básico de la figura de Jesús, para el gran público: Iniciación a Jesús de Nazaret, Sal Terrae, Santander 2014.

\section{Otros ESTUdios, EDICIÓn de CONJUNTo del Nuevo Testamento}

Como he venido diciendo, desde los años de nuestra docencia común (1980-1984), S. Vidal había previsto y programado un estudio de conjunto de todos los textos del Nuevo Testamento, primero por separado (a través de estudios parciales), y después de un modo unitario. Entre los estudios "parciales" (además de los ya señalados sobre Pablo y la historia de Jesús) sobresalen los dedicados al "corpus de Juan", a través de una obra que ha tenido dos versiones distintas.

La primera se titulaba: Los escritos originales de la comunidad del discípulo amigo de Jesús El evangelio y las cartas de Juan (Sígueme, Salamanca 1997). El proceso de surgimiento de las obras de la comunidad del discípulo "amigo" de Jesús constituye uno de los enigmas y aportaciones mayores no sólo del Nuevo Testamento, sino de la vida y teología del cristianismo. Muchos especialistas habían señalado, de un modo más o menos convergente, ese proceso. Lo que no se había hecho, que sepamos, es una presentación pormenorizada de los textos, así divididos y aclarados, en sus diversos momentos, con el original griego y una ajustadísima traducción castellana, en perfecta y distinta grafía para cada caso.

Por siglos se han situado, comentado y expandido las obras del "discípulo amigo" sin tener en cuenta el proceso y momentos de su desarrollo. Pues bien, S. Vidal ha mostrado que ellas son fruto de una comunidad que ha vivido de algún modo separada de otros grupos antiguos de la iglesia, cultivando un recuerdo especial de Jesús y elaborando de manera autónoma sus tradiciones. Pasados los años, tras un proceso de crecimiento, ajuste y crisis, algunos miembros de esa comunidad vinieron a integrarse en la Gran Iglesia (representada por Pedro), llevando el tesoro de sus libros, debidamente adaptados. La historia de esa comunidad se ha expresado en el texto actual del evangelio y las cartas de Juan, que han surgido a partir de tradiciones sueltas $(\mathrm{T})$, de una colección de milagros (CM) y de un relato de la pasión (RP). A partir de esas tradiciones, un primer redactor ha fijado el texto base del evangelio (E1), que a lo largo de los años ha sido transformado (E2) y glosado (E3) por los redactores actuales del evangelio. Construido de esa forma, el evangelio actual ha sufrido pocas variaciones (algún cambio de orden, alguna añadidura, 
como la de 7, 53-8,1). Más tarde, en un proceso paralelo de ajuste de tradiciones, han ido surgiendo las tres cartas (1Jn, 2Jn y $3 \mathrm{~J}$ ).

Pasados los años, en el proceso de relectura y fijación más precisas del despliegue del Nuevo Testamento, S. Vidal ha precisado y expuesto su investigación sobre el "discípulo amigo" en una obra magistral, del gran envergadura (686 págs.) titulada: Evangelio y cartas de Juan. Génesis de los textos joánicos, Mensajero/Loyola (del grupo de Sal Terrae), Bilbao 2013. De esa forma, pasados dieciséis años de la publicación de la anterior (Los escritos originales... 1997), S. Vidal quiso recoger el resultado de su investigación en esta obra que será por años un lugar de referencia obligada para el estudio de la comunidad de Juan, dentro del despliegue (surgimiento y fijación) del Nuevo Testamento, a partir de las diversas tendencias y tradiciones de las iglesias.

Avanzando en esa línea, para completar el abanico de tendencias eclesiales del Nuevo Testamento, como preparación para su estudio de conjunto de la tradición sinóptica, S. Vidal ha querido ofrecer también el resultado de su investigación inicial sobre los sinópticos en una obra titulada El documento Q. Los primeros dichos de Jesús, Sal Terrae, Santander 2011. Tuvimos ocasión de hablar varias veces de ella, especialmente en el tiempo en que yo estaba preparando mi Comentario de Marcos (Verbo Divino, Estella 2012), que él situaba en el contexto de la iglesia helenista de Damasco, cerca de la Alta Galilea y Fenicia, frente a Mateo, que debía situarse en Antioquía, y frente Lucas, que, a su juicio, había escrito su obra en Éfeso, en un lugar cercano al de la tradición del discípulo Amigo, aunque en comunidades distintas. Su aportación, sus observaciones, fueron decisivas en mi elaboración no sólo del Comentario de Marcos, sino del de Mateo, que yo estaba ultimando cuando él murió.

S. Vidal era consciente de que le faltaban todavía muchos estudios de base, no sólo sobre el Apocalipsis y los evangelios sinópticos, con los escritos posteriores de la escuela paulina (Pastorales), las cartas "católicas" y el "discurso" a los Hebreos. Durante muchos años le pedí que me ofreciera sus apuntes sobre Hebreos y que los unificara para publicarlos en la colección de GLNT, de Verbo Divino. Pero siempre me dijo que le sobraban materiales y le faltaba tiempo, que más adelante, que necesitaba varios años para publicar primero su Nuevo Testamento y su Historia del Cristianismo Primitivo.

Pero, por desgracia, no ha habido tiempo para ello, pero sí lo hubo, por gracia de Dios y por empeño de su editor, para la publicación su obra más extensa, con el compendio de su investigación de decenios: Nuevo 
Testamento. Edición preparada por Senén Vidal, Sal Terrae, Santander 2015. Se trata de una obra cumbre, por contenido y dimensiones, a gran formato, de 1302 págs., que ofrece una condensación y resultado de gran parte de sus trabajos anteriores. Es, posiblemente, la obra más importante de la exégesis y teología en lengua castellana de los últimos decenios. Digo posiblemente, porque las comparaciones son odiosas (y con frecuencias falsas), y hay además otras obras importantes (como la del Prf. Luis Alonso Schökel: Nuevo Testamento, en Biblia del Peregrino, edición de estudio 1989, aunque con una orientación distinta, de tipo más literario).

Pues bien, con esas salvedades, mantengo lo dicho: Estamos ante una obra cumbre: En plena madurez creadora, recogiendo y condensando trabajos anteriores, Senén Vidal ha publicado una de las obras más importantes de la teología y vida cristiana de los últimos tiempos. Nadie, que yo sepa, ha realizado una traducción y comentario semejante de todo el Nuevo Testamento. Sólo Senén, después de más de treinta años de preparación, ha podido realizar una obra de esta envergadura. (a) Es una obra extensa (1300 páginas), a gran formato, notable por su orientación y contenido: Una presentación rigurosa y ceñida de cada uno de los libros, con una visión de conjunto de su origen y de sus diversos elementos, con introducciones y notas en las que se sitúa y describe el sentido y lugar de cada uno de los libros y sus diversas secciones. (b) Esta obra recoge una parte considerable de los libros y trabajos anteriores de Senén Vidal, que le han permitido conocer y presentar los textos básicos del Nuevo Testamento, a través de las monografías que he venido presentando. He seguido bastante bien la producción bíblica hispana, y eso me permite decir (sin minusvalorar a otros investigadores) que nos hallamos ante una obra cumbre de la exégesis y teología bíblica en lengua castellana. Este libro (traducción y comentario de todo el NT) recoge la investigación anterior de Senén Vida, condensada en los siguientes libros: (a) Las cartas originales de Pablo (Bilbao 2013). (b) Evangelio y Carta de Juan. Génesis de los textos juánicos (2013). (c) El documento Q: los primeros dichos de Jesús (Santander 2011). (d) Carta a los Tesalonicenses 1: El primer escrito cristiano (Salamanca 2006) (e) Colosenses y Efesios (Estella 201), (e) Hechos de los Apóstoles y orígenes cristianos (Santander 2015). En esa línea, ésta no es una obra totalmente nueva, sino que recoge y condensa la investigación anterior. Nuevas son sólo las partes dedicadas a los sinópticos, las pastorales, las "cartas católicas” y el Apocalipsis. 
Éstas son sus cuatro aportaciones fundamentales. (1) Una traducción nueva, que recoge en forma actual (en lenguaje comprensible y cercano) la palabra y mensaje de la Biblia. Son muchas las traducciones del NT que hoy existen, y algunas muy valiosas. Ésta tiene la ventaja de la "cercanía" al texto original, sin apegarse nunca de un modo literal a los originales. Es una obra exacta y literaria al mismo tiempo, coloquial y científica a la vez. Es una pena que no se haya puesto al lado el texto griego del NT, para uso escolar, aunque quizá ampliaría demasiado el volumen de la obra. (2) Introducciones a cada sección y libro, en las que se condensa lo mejor que actualmente se puede afirmar sobre el surgimiento y desarrollo de los textos del NT, con sus divisiones y sus posibles tradiciones anteriores, tanto en los evangelios como en Pablo. Son por necesidad breves, pero van directamente a lo esencial, sin detenerse en un tipo de erudición innecesaria. En esa línea, como obra de conjunto, este libro podría dividirse en cuatro o cinco obras mejores, cada una plenamente valiosa. (3) Son fundamentales las notas, entendidas en plano literario e histórico (y a veces teológico). No son notas de interpretación "confesional" (católica, protestante...), pues el libro se sitúa por encima de esas divisiones, allí donde el NT aparece en su radicalidad como testimonio del primer cristianismo, antes de las separaciones confesionales. Destacan las de tipo literario, poniendo de relieve el origen de cada texto, y situándolo dentro del despliegue del cristianismo primitivo. (4) Todo el trabajo (tanto de traducción, como de introducciones y notas) es "de primera mano". Ciertamente, S. Vidal recoge la mejor investigación bíblica de los últimos decenios (y siglos), pero la reformula desde su propia perspectiva, de un modo personal. Por eso no apela casi nunca a lo que dicen otros, sino que expone su propia visión personal y directa de los temas, como producto de un trabajo de decenios sobre el texto.

En el fondo, este libro realiza una gran labor apologética, en el sentido radical del término, es decir, como "defensa del texto" contra todos aquellos que, de un modo o de otro, critican el cristianismo rechazando la veracidad o sentido de la Biblia (del NT). Pues bien, sin ninguna intención partidista, sin ninguna crítica de los posibles "contrarios", Senén Vidal se limita a presentar el texto del NT, a traducirlo y exponerlo, de un modo conjunto, para dar así razón de la novedad de la experiencia cristiana, tal como se expresa en los primeros escritos de la iglesia. 


\section{TAREA ABIERTA, UNA OBRA PENDIENTE: Historia DEL CRISTIANISMO PRIMITIVO}

En el momento de su muerte, S. Vidal se hallaba en plena producción intelectual. Su obra cumbre (El Nuevo Testamento) había aparecido el 2015, y el 2016 apareció su libro sobre la Resurrección. Pero, a mi juicio, y según su confesión, su obra programática final se titulaba Hechos de los apóstoles y orígenes cristianos, Sal Terrae, Santander 2015, 176 págs. Me la entregó con todo interés, pidiéndome un juicio y una orientación, pues sobre esta pista, me dijo, debemos seguir trabajando, para precisar el sentido y camino de los orígenes cristianos, desde nuestra situación histórica, a comienzos del tercer milenio.

Él había cumplido casi el programa de su investigación, tal como la habíamos trazado en torno al año 1980. Yo había sido menos cumplidor, pero me estaba acercando a la misma meta (tras mi Historia de Jesús y los comentarios sobre el Apocalipsis y a los Sinópticos: Mc y Mt). Nos quedaba un estudio convergente sobre los orígenes cristianos, y podíamos hacerlo por separado, él en sentido más histórico-literario, yo más teológico, para compulsar al fin nuestras perspectivas. Con esa finalidad me pidió que leyera y comentara este libro sobre Hechos, que leí con pasión, sabiendo que se trataba de una obra de gran autoridad, y así le dediqué una página de mi blog, que aquí en parte retomo (periodistadigital.com/xpikaza.php/2015/04/14/p367162\#more367162).

Hace unos veinte años se había discutido con pasión el tema de la historia de Jesús. Actualmente (2015), ese tema parece menos central. Sin duda, sigue apasionando a muchísimos lectores, de forma que son bastantes los que tratan (tratamos) de plantearlo del mejor modo posible. Pero hoy importa más y se discute más el surgimiento y sentido de la historia de la Iglesia, pasando así de Jesús a sus primeros seguidores, retomando críticamente el camino iniciado por Hechos.

Otros grandes "testigos" cristianos (Marcos y Mateo, Pablo y Juan...) no tuvieron necesidad de escribir sobre la historia de la iglesia, porque a su juicio el origen y sentido de la iglesia se hallaba vinculado de tal forma a Jesús que resultaba imposible estudiarlo de manera separada. El primero que ha dado "autonomía" a la historia de la iglesia, dedicándole un tratado ha sido Lucas, autor de dos obras complementarias: El evangelio (Lc) y el libro de los Hechos de los Apóstoles. De tal forma y con tal autoridad escribió Lucas este segundo libro (Hechos) que ha marcado hasta el día de hoy la visión de la historia de la Iglesia. 
Sólo ahora, a comienzos del siglo XXI, estamos redescubriendo (al menos desde una perspectiva católica) el carácter especial del libro de los Hechos, que no cuenta "la" historia única de la iglesia primitiva, sino que ofrece una interpretación muy particular de su despliegue, en línea de "tesis" (dejando a un lado otros datos y tendencia eclesiales). Por eso, sólo "de-construyendo" la interpretación de Hechos, recuperando sus posible materiales más antiguos y conociendo sus "tesis" podremos valorar plenamente otras fuentes del NT (Pablo, tradición evangélica etc.), para "re-construir" la historia de la Iglesia (o mejor, de las iglesias) del principio del cristianismo. Sólo desde ese fondo se entiende la intención de Senén Vidal, que ha querido recuperar las fuentes ocultas del libro de los Hechos, para ir rastreando y precisando mejor aquellas tradiciones más antiguas, que no concuerdan plenamente con la intención del autor de la obra (de Hechos). De esa manera, reconociendo los materiales más antiguos y fijando la intención histórico-teológica de Lucas, podemos interpretar mejor el origen del cristianismo.

1. Lucas-Hechos, una obra doble, escrita probablemente en Éfeso. Entre el 90 y el 100 d.C., un cristiano culto, de origen probablemente pagano, que pudo haber sido prosélito judío y conocía bien la Biblia Griega (los LXX), quiso escribir la primera historia de Jesús y de su movimiento, siguiendo modelos judíos y helenistas. Su relato empieza así: "Ya que muchos han intentado componer un relato (diéguesis) de las cosas (pragmatôn) que han sucedido entre nosotros, según aquello que nos han transmitido los primeros testigos oculares, convertidos en servidores de la Palabra, también yo, después de investigar todo con diligencia, desde los orígenes, he decidido escribírtelo con orden, ilustre Teófilo, para que compruebes la solidez de las enseñanzas que has recibido» (Lc 1,1-4).

Pues bien, ese cristiano a quien solemos llamar "Lucas" (aunque quizá no tuviera ese nombre) escribió una obra de dos partes (Lc y Hech), algunos dicen que en Roma, porque allí culmina la segunda parte (Hechos); Senén Vidal se inclinó por Éfeso, por la importancia de esa iglesia, porque en su entorno surgieron las cartas de la cautividad (Colosenses y Efesios) y porqué allí se escribirán más tarde el Apocalipsis y las Cartas Pastorales. Ciertamente, según Hechos, Roma es para Pablo el punto de llegada, pero el lugar de su último mensaje o «testamento», según Hechos, es la comunidad de Éfeso, a cuyos ancianos dirige un discurso programático (cf. Hch 20,1738). 
Todo nos permite suponer que en este momento (en torno al 90/100 d.C.) la memoria de Pablo no era todavía dominante en Roma, una Iglesia de tipo más judeo-cristiano, quizá más vinculada a Pedro (cf. cap. 18), mientras que Éfeso constituía el lugar de cruce de la mayor parte de las tendencias cristianas, pues allí pervivía la tradición paulina y allí llegaron diversos grupos judeo-cristianos, tras la guerra del 67-70 d.C. Sabemos mejor la manera en que Lucas compuso su evangelio, porque no sólo conocemos sus fuentes básicas (Marcos y Q), sino que contamos también con otras obras con las que la suya puede compararse (Mateo y Juan). Pero la situación respecto a Hechos es totalmente distinta, pues no conservamos sus fuentes (de manera que sólo podemos recuperarlas rastreando su texto), ni contamos con otras "historias alternativas", escritas, por ejemplo desde la misión judeo-cristiana de Santiago, desde la perspectiva posterior de la tradición de Pedro o desde las iglesias de Siria o Corinto. El libro de los Hechos ha quedado así como único testimonio de una historia de la Iglesia más rica y discutida.

2. Hechos, una historia parcial. Lucas ha sido el escritor cristiano que ha tenido una conciencia más clara de un tipo de identidad social de la Iglesia y del lugar que ella ocupa en la historia, como un movimiento mesiánico derivado de Jesús, con su propia "entidad" (identidad) en el mundo, pero su escrito es una obra de "tesis": No cuenta cómo pasaron las cosas, sino cómo se entienden desde la perspectiva de una misión paulina que ha desembocado en Roma.

Desde ese fondo se entienden los dos polos de la historia de Hechos. (a) El polo judío, que forma la raíz, que se debe mantener, pues recoge el origen y destino israelita de Jesús (todo Lc), el principio jerosolimitano de la iglesia (Hch 1-15). Desde ese fondo ha idealizado Lucas los orígenes jerosolimitanos de la iglesia, en torno a Pedro y a los doce (en contra del origen real de las iglesias o comunidades que fue más amplio y plural, desde el principio, con gran influjo galileo y de otras iglesias como las de Siria, en especial la de Damasco). (b) El polo helenista o romano constituye el encuadre final y definitivo de la iglesia, pues Pablo ha llegado a Roma y se encuentra allí preso, pero anuncia abiertamente el evangelio (Hch 28). Esa visión de la Iglesia, centrada en Pablo que llega a Roma es muy sugerente, pero deja a un lado otras perspectivas e iglesias (en especial las del polo judío o de Siria y el Asia Menor, con Grecia y quizá Alejandría). 
Dentro de ese doble entorno (judío y romano), sabiendo que la restauración del reino de Israel queda pendiente (Hch 1, 6-7), en manos de Dios, Lucas ha querido escribir una historia central de la iglesia, que va de Jerusalén a Roma, realizando así una opción que ha sido trascendental para la historia posterior del cristianismo. Indudablemente, Lucas conoce otras "historia" que podrían contarse, otras visiones de la Iglesia, y sabe que la historia de los primeros cristianos se podría haber escrito de manera diferente. Pero, a su juicio, en el fondo de las diversas Iglesias late y se expresa un único camino, una trayectoria que va de Jerusalén a Roma.

Esa visión de la Iglesia, que va avanzando de Jerusalén a Roma, refleja según Lucas la obra del Espíritu Santo, que aparece así como auténtico protagonista del relato cristiano. Ciertamente, hay otros personajes valiosos, que dominan por un tiempo la trama del libro de los Hechos (los Doce y Pedro, los helenistas y Esteban, Felipe, Santiago...), pero todos ellos acaban quedando siempre en un segundo plano. Actúan por un momento y desaparecen (cumplida ya su función), de manera que la unidad y continuidad cristiana queda garantizada por la acción del Espíritu, que va llevando a la Iglesia desde Jerusalén (con los Doce y Pedro), hasta Roma, de la mano de Pablo, que llega para ser juzgado hasta la capital del imperio.

Así se cumple el "argumento" de Hechos, formulado por el mismo Jesús antes de su "ascensión" al cielo. "Recibiréis la Fuerza del Espíritu Santo, que vendrá sobre vosotros. Y seréis mis testigos en Jerusalén, y en toda Judea y en Samaria, y hasta los confines de la tierra..." (Hch 1, 8-9). Esta es la trama, que va pasando de Pedro y los Doce, a través de la misión de los helenistas, hasta Pablo, que ocupa el centro de la Historia, desde Hech 15 en adelante, como portador de un camino de evangelio que llega a Roma.

3. De la historia central a las "historias truncadas" (es decir, no narradas). Ésta ha sido para Senén la historia central de Hechos, que nos lleva de la Iglesia presuntamente unitaria de Jerusalén a la Iglesia conflictiva de Roma, donde Pablo sigue preso. De esa manera ha trazado Lucas una visión unitaria del Cristianismo, aunque para ello tiene que ir dejando al lado (o expulsando de su narración) muchos cabos sueltos, con los helenistas y Esteban, con Felipe y las iglesias de Galilea, de Damasco y Samaría, con los parientes de Jesús y las mujeres amigas, con los cristianos de Alejandría y la misión de los "judaizantes", en competencia con Pablo. 
Pues bien, para recuperar esas "historia truncadas" o conservadas en otros testimonios que no han querido ser directamente "históricos", como las cartas de Pablo (con los sinópticos y Juan, con los autores de las cartas católicas y el Apocalipsis) ha escrito Senén Vidal esta impresionante "deconstrucción" creadora del libro de los Hechos. No ha querido "construir" directamente esas historias, pero deja abierto el hueco donde ellas pueden situarse. Lo hace de un modo sobrio, acudiendo siempre a los textos e interpretándolos de primera mano, con autoridad propia, apelando siempre a su propio magisterio, tras cuarenta años de intensa enseñanza bíblica.

Éste fue el objeto de nuestra última conversación, semanas antes de su muerte. Tanto él como yo éramos personalmente muy sobrios. Compartíamos perspectivas, discutíamos matices, pero sin que uno entrara en el campo de investigación directa del otro, cosa que ahora lamento intensamente. Si hubiera previsto su muerte, le hubiera pedido "materiales"; le hubiera dicho que me dejara ver sus borradores de la historia del cristianismo primitivo, y yo le hubiera dejado los míos. Pero no lo hice, y ahora lo siento, pues sólo conozco la orientación básica de su pensamiento, tal como la acabo de exponer, y no lo que sería la Historia del Cristianismo Primitivo que él estaba preparando (que los dos queríamos escribir al mismo tiempo, y de alguna forma unidos).

No sé si se conservan loa materiales y esbozos de esa Gran Historia del cristianismo primitivo que Senén estaba planeando. Me gustaría mucho que existieran y se publicaran, ahora que, tras su muerte, me siento algo más "huérfano" en sentido personal (de amistad) y en el intelectual. He perdido a mi mejor crítico, me falta el mejor punto de referencia. Pero quiero seguir en su línea, el tiempo que Dios me ofrezca, e intentaré escribir en su honor (en honor de Senén) mi versión, más teológica, más genérica, de la Historia del Cristianismo primitivo, si Dios me da tiempo y salud para ello. Lo haré recordando lo que hubiera sido el libro de Senén, después de más de cincuenta años de amistad. Lo haré en mi nombre, y en el de Mabel, que me decía, de tiempo en tiempo: "Llama a Senén, tenéis que encontraros más veces". No nos encontramos, quizá, las suficientes, pero las veces que lo hicimos fueron memorables, como aquí he querido poner de relieve. 